\title{
The Advisory Board for Research Development
}

IUGS has long been conscious of the very special requirements for international cooperation in the geosciences, and it has a policy of encouraging regional and global geoscientific projects. Some years ago the Union's Executive Committee established an Advisory Board for Research Development to advise it on actions to stimulate, encourage and facilitate geoscientific research that will advance knowledge and aid the solution of regional and global socioeconomic problems.

These activities fall into three broad categories:

- major long-term global international programs such as IGCP and ILP;

- more specific, resource-related projects of particular interest to developing countries, such as the Mineral Deposit Modelling project, and

- regional projects where international cooperation is particularly important, such as the Circum-Atlantic map project.

The Board, chaired by the writer, examines project proposals and examines ways in which projects can be best developed in relation to existing IUGS programs. The International Geological Correlation Programme, in collaboration with Unesco, has long been the centrepiece of the IUGS program, and a model for international cooperation in science. Similarly the International Lithosphere Program has established itself as an important vehicle for international collaboration between IUGS and IUGG. More recently the Board has encouraged the development of the Global Sedimentary Geology Program, which is aimed at the analysis of sedimentary facies development in space and time.

Like the IGCP Board and Scientific Committee, the ABRD recognizes the critical importance of leadership in developing international projects. The most successful projects have had leaders with abundant energy and enthusiasm who provide scientific leadership, and who also generate additional funding under the aegis of IUGS.
Recently, ABRD has paid special attention to the development of IUGS participation in IGBP, the International Geosphere-Biosphere Program. This culminated in April 1989 in a workshop in Interlaken, Switzerland, set up by the IUGS Task Force on Global Change (see news report elsewhere in this issue - Ed.).

The Board believes that the scope of IUGS activities is broadly appropriate and that the various programs are making important contributions to the development of the geosciences. However the Board is concerned about obtaining the best balance of activities within the limited resources available to the Union.

In recent years it has been recognized that IUGS should be focussing more effort on environmentally related issues under programs such as IGBP and the International Decade for Natural Disaster Reduction. At the same time, resource-related issues remain of great importance to developing countries, and the Mineral Deposit Modelling project is continuing with significant support from the U.S. Geological Survey and from Unesco. The Advisory Board on Remote Sensing is also developing extensions of the $\mathrm{Geo}^{-}$ logical Applications of Remote Sensing Project (GARS). The Board would like to see such special initiatives recognized as sufficiently important to be self-supporting.

In reviewing IUGS programs, the Board notes that IGCP has successfully developed a number of regional projects in South America but that further encouragement needs to be given to the development of effective cooperative programs in Africa. The Board is also considering ways in which IUGS can contribute to international communication in the context of recent developments in information technology.

The Board currently operates with a small membership and holds meetings in conjunction with other meetings, so as to allow a wide range of other geoscientists to attend and to provide their insights. Indeed ABRD welcomes contributions to the discussion of key issues.

R.W.R. Rutland

Canberra, Australia (Chairman, ABRD) 